\title{
PERLINDUNGAN KONSUMEN TERHADAP PEMASANGAN IKLAN SHORT MESSAGE SERVICE PADA PERUSAHAAN TELEKOMUNIKASI TELKOMSEL DI KOTA MAKASSAR
}

\author{
Juwenie Mangiri \\ Universitas Kristen Indonesia Paulus, juwenimangiri94@gmail.com
}

\begin{abstract}
Abstrak
Perkembangan teknologi informasi saat ini telah memberikan dampak signifikan dalam perkembangan transaksi bisnis dalam sistem perdagangan. Salah satu bentuk penerapan teknologi informasi tersebut adalah dalam penyampaian iklan terhadap calon konsumen barang dan jasa melalui media Short Message Service (SMS). Penggunaan media SMS tentu sangat menguntungkan perusahan telekomunikasi dan pelaku usaha. Namun, tidak semua konsumen perusahaan telekomunikasi merasa nyaman dengan adanya pesan singkat berisi iklan tersebut. Karena itu, artikel ini menganalisis perlindungan konsumen terhadap pemasangan iklan melalui media SMS pada PT Telkomel di Kota Makassar. Selain itu, artikel ini juga akan melihat keuntungan dan kerugian bagi konsumen sebagai akibat dari pemasangan iklan melalui media SMS. Tujuan penulisan untuk mengetahui perlindungan hukum terhadap konsumen dan keuntungan serta kerugian bagi konsumen terhadap pemasangan iklan pada PT Telkomsel melalui SMS di Kota Makassar. Hasil dari penelitian menunjukkan bahwa perlindungan konsumen melindungi konsumen dari perbuatan pelaku usaha yang dalam mengiklankan produknya melalui SMS sudah melanggar hak-hak konsumen yang jelas di atur dalam Undang- Undang Nomor 8 Tahun 1999 tentang Perlindungan Konsumen, serta mengetahui bahwa adanya iklan melalui SMS lebih banyak merugikan konsumen terlebih dari segi privasi konsumen.
\end{abstract}

Kata kunci : Perlindungan Konsumen; Pelaku Usaha; Iklan SMS

\begin{abstract}
The development of information technology now has a significant impact on the development of business transactions in the trading system. One of the application of information technology is in the delivery of advertisements to potential consumers of goods and services through the media Short Message Service (SMS). The usage of SMS media is certainly very beneficial for telecommunications companies and business operators. However, not all the consumers of telecommunications companies feel comfortable with the short message containing the advertisement. In hence, this article analyzes consumer protection against advertising through SMS media at PT Telkomel in Makassar City. This article will also look at the advantages and disadvantages for consumers as a result of advertising through SMS media. The purpose of writing to determine the legal protection of consumers and the advantages and disadvantages for consumers against advertising on PT Telkomsel via SMS in the city of Makassar. The result of the study indicate that consumer protection protects consumers from the actions of business actors who in adversiting their products throught SMS have violated consumer rights which are cleary regulated concerning Consumer Protection, and know that the existens of advertisements through SMS in more harmful consumers especially in terms of consumer privacy.
\end{abstract}

Keywords: Consumer Protection; Businessmen; SMS Advertisement 


\section{Pendahuluan}

Pada era globalisasi dan perdagangan bebas yang sedang kita hadapi saat ini, tidak bisa kita memungkiri bahwa persaingan bisnis atau usaha semakin ketat, di buktikan dengan banyaknya bermunculan berbagai macam produk barang atau pelayanan jasa yang di pasarkan kepada konsumen baik melalui promosi, iklan maupun penawaran secara langsung. Kemajuan teknologi informasi yang sangat pesat menimbulkan suatu adanya gaya baru dalam sistem perdagangan. Hal ini pun tidak di sia-siakan oleh para pelaku usaha untuk memakai teknologi sebagai media atau sarana untuk mempromosikan dan mengiklankan jenis usaha yang mereka miliki.

Iklan adalah salah satu bentuk penyampaian informasi dari barang dan jasa dari pelaku usaha kepada konsumennya, maka dari itu iklan mempunyai kedudukan yang penting bagi pelaku usaha sebagai alat untuk membantu memperkenalkan produk atau jasa yang ditawarkan kepada konsumen. Tanpa adanya iklan berbagai produk barang dan jasa tidak dapat mengalir secara lancar sampai ke tangan konsumen atau pemakainya. Pemasangan iklan yang dilakukan para pelaku usaha bisa diterapkan dengan berbagai cara seiring berkembangannya ilmu teknologi dan informasi. Seperti melalui media cetak (koran, majalah, brosur, dan lain-lain), media elektronik (televisi, radio, dan lain-lain) serta telephone seluler. Salah satu pemasangan iklan menggunakan telephone seluler adalah dengan cara mepromosikan dan mengiklankan jenis usaha mereka melalui pesan singkatyaitu Short Message Service yang selanjutnya akan disebut SMS. Menurut Arens, iklan dikatakan sebagai komunikasi informasi yang terstruktur dan disusun bukan oleh perseorangan, biasanya dibayar untuk dan secara alami umumnya membujuk tentang produk (barang,jasa) yang diidentifikasi sponsor lewat berbagai media. ${ }^{1}$

Pemasangan iklan oleh pelaku usaha melalui SMS sekarang sudah marak terjadi, dikarenakan pada zaman sekarang teknologi sudah sangat maju, tentunya setiap orang atau individu sudah mempunyai masing-masing telephone seluler yang membantu untuk kita berkomunikasi dengan orang lain serta dan itulah yang dimanfaatkan sebagai sarana perdagangan atau bisnis dengan memanfaatkan teknologi yang ada tersebut pelaku usaha dapat dengan mudah mengiklankan dan mempromosikan barang dan jasa tepat pada sasaran karna dengan SMS setiap pesaniklan yang pihak operator kirim dalam hal ini adalah perusahaan telekomunikasi, dapat dengan cepat dan mudah diterima oleh para konsumen, itulah salah satu manfaat dari adanya pemasangan iklan menggunakan telephone seluler yaitu melalui SMS, tentunya hal tersebut tidak dapat terjadi jika pelaku usaha tidak bekerja sama dengan pihak perusahaan telekomunikasi.

\footnotetext{
1 Aren Lubis, (2007), Teori-teori Periklanan Dan Unsur Periklanan, Universitas Indonesia, Jakarta
} 
Perusahaan telekomunikasi itu sendiri akan mengirimkan SMS kepada para konsumennya yang mana isi pesan singkat tersebut berupa iklan ataupun promosi barang dan jasa yang ditujukan kepada konsumen. Tetapi tidak semua konsumen dapat menerima setiap SMS tersebut dengan situasi yang menyenangkan bagi mereka, karna ternyata pemasangan iklan menggunakan telephone seluler, yaitu SMS dapat mengganggu kenyamanan para konsumen yang menerima pesan iklan tersebut.

Fenomena pemasangan iklan oleh para pelaku usaha melalui SMS inipun sangat menguntungkan bagi perusahaan telekomunikasi dan pelaku usaha yang tentunya dua pihak ini sudah melakukan perjanjian pemasangan iklan yang melibatkan konsumen perusahaan telekomunikasi tersebut. Dalam perjanjian yang dilakukan kedua belah pihak ini pasti masing-masing mempunyai kedudukan yang tercantum dalam perjanjian yang mereka telah sepakati, tetapi konsumen yang menjadi sasaran pengiriman SMS yang berisikan iklan tidak diketahui kedudukannya dalam perjanjian tersebut, bagaimanapun konsumen tetap mempunyai hak, karena dalam pemasangan iklan melalui SMS konsumenlah yang menjadi tujuan utama pelaku usaha dan perusahaan telekomunikasi dalam mencari keuntungan.

Beberapa contoh kasus tersebut diatas terjadi pada waktu yang lalu dimana saya mendapati seorang konsumen yang mengeluh dan berpendapat bahwa dengan adanya pesan SMS berupa iklan usaha makanan cepat saji yang masuk ke nomornya dengan jumlah yang cukup banyak setiap ia melewati jalan yang terdapat tempat usaha tersebut dan ia juga mendapat SMS berisikan iklan usaha makanan cepat saji lainnya yang pesannya dikirim itu tidak mengenal waktu, kadang pagi, siang bahkan malam hari ketika sedang beristirahat yang tentunya menganggu kenyamanan dan ketenangannya, kemudian ia mengeluh juga dikarenakan ada beberapa SMS yang sebenarnya tidak ia inginkan tetapi tetap ia terima, selain itu membuat kotak masuk SMS penuh dan dampaknya telephone seluler yang ia punya oprasional sistemnnya menjadi lambat, dan pada SMS yang masuk langsung tertera nama perusahaan yang dimiliki para pelaku usaha yang tentunya sudah bekerja sama dengan perusahaan telekomunikasi tersebut, sedangkan nama perusahaan tersebut tidak pernah menjadi daftar kontaknya , maka hal yang seperti ini tentunya sudah di rencanakan oleh kedua belah pihak. SMS berbau informasi itu penting, namun tentu ia berfikir bahwa operator dalam hal ini adalah perusahaan telekomunikasi harus memikirkan faktor kenyamanan dari konsumen atau pelanggannya.

Perlindungan konsumen adalah keseluruhan kaidah-kaidah hukum yang mengatur hubungan dan masalah antara berbagai pihak satu dengan lain berkaitan 
dengan barang dan/atau jasa konsumen didalam pergaulan hidup. ${ }^{2}$ Di dalam Pasal 1 angka (1) Undang-Undang Nomor 8 Tahun 1999 tentang Perlindungan Konsumen menyatakan definisi dari perlindungan konsumen tersebut adalah segala upaya yang menjamin adanya kepastian hukum untuk memberi perlindungan kepada konsumen. Perlindungan Konsumen memiliki istilah yang berkaitan dengan perlindungan hukum, oleh karena itu perlindungan konsumen mengandung aspek hukum. Perlindungan hukum merupakan perlindungan yang diberikan hukum terkait mengenai hak dan kewajiban manusia.

Mengingat lemahnya kedudukan konsumen pada umumnya dibandingkan dengan kedudukan produsen yang relatif lebih kuat dalam banyak hal misalnya dari segi ekonomi maupun pengetahuan mengingat produsenlah yang memproduksi barang sedangkan konsumen hanya membeli produk yang telah tersedia dipasaran, maka pembahasan perlindungan konsumen akan selalu terasa aktual dan selalu penting untuk dikaji ulang serta masalah perlindungan konsumen ini terjadi di dalam kehidupan sehari-hari, terlebih dalam perkembangan teknologi para penawar barang dan jasa atau biasa disebut pelaku usaha akan memanfaatkan teknologi informasi sebagai media untuk meiklankan dan mempromosikan barang dan jasanya, misalnya melalui internet atau short message service (SMS) yang masuk ke nomor telephon seluler yang konsumen miliki dan dapat menganggu kenyamanan serta keamanan para konsumen.

Berdasarkan uraian latar belakang di atas, perumusan masalah dalam penelitian ini adalah bentuk perlindungan konsumen terhadap pemasangan iklan pada PT Telkomsel melalui SMS di Kota Makassar. Selain itu, penelitian ini juga menganalisi tentang keuntungan dan kerugian bagi konsumen terhadap pemasangan iklan dari PT Telkomsel melalui SMS di Kota Makassar.

\section{Metode}

Jenis penelitian ini termasuk penelitian hukum yang sosiologis yang memandang hukum sebagai fenomena sosial, dimana membutuhkan data-data yang lengkap untuk mengidentifikasi suatu hal secara empiris dan data sekunder sebagai dasar kekuatan mengikat ke dalam. Dalam hal memperoleh data yang sesuai, dan mencakup permasalahan dalam penulisan proposal skripsi ini, penulis menggunakan beberapa teknik pengumpulan data yang kan dilakukan, yakni kuisioner, wawancara, dan kepustakaan. Studi dokumen bagi penelitian hukum meliputi studi terhadap bahan-bahan hukum yang terdiri dari bahan hukum primer, dan bahan hukum sekunder. Bahan hukum primer yaitu peraturan perundangundang, yaitu Undang-Undang Nomor 8 Tahun 1999 tentang Perlindungan

\footnotetext{
${ }^{2}$ Sidarta Gautama, (2004), Hukum Perlindungan Konsumen Indonesia, Edisi Revisi, Grasindo, Jakarta, hal. 9
} 
Konsumen. Sedangkan bahan hukum sekuder terdiri dari buku, jurnal, bahan penelitian terdahulu, dan artikel terkait dengan isu yang dibahas.

\section{Pengaturan di Bidang Periklanan}

Iklan merupakan salah satu alat yang digunakan dalam proses perdagangan untuk memperlihatkan dan menjual produk perusahaan kepada masyarakat tertentu. Jenisnya bisa dengan menggunakan elemen verbal dan visual melalui berbagai media yang dianggap efektif. Periklanan adalah bagian yang tidak dapat dipisahkan dari bisnis modern, di mana iklan dianggap sebagai media ampuh untuk menonjol dalam persaingan. Iklan adalah pesan komunikasi pemasaran tentang suatu produk yang disampaikan melalui suatu media, dibiayai oleh pemrakarsa yang dikenal, serta ditujukan kepada sebagian atau seluruh masyarakat. ${ }^{3}$ Menurut Kamus Besar Bahasa Indonesia, iklan adalah pesan komunikasi dari produsen/pemberi jasa kepada calon konsumen di media yang pemasangannya dilakukan atas dasar pembayaran. Periklanan adalah proses pembuatan dan penyampaian pesan yang dibayar dan disampaikan melalui sarana media massa yang bertujuan membujuk kosumen untuk melakukan tindakan membeli/mengubah perilakunya. Periklanan adalah komunikasi komersil dan nonpersonal tentang sebuah organisasi dan produk-produknya yang ditransmisikan ke suatu khalayak target melalui media bersifat massal seperti televisi, radio, koran, majalah, pengiriman pesan secara langsung (direct mail). ${ }^{4}$

Secara umum, periklanan dikenal sebagai pelaksana beragam fungsi komunikasi yang penting bagi perusahaan bisnis dan organisasi yaitu Pertama, memberi informasi (Informing). Dalam hal ini, periklanan membuat konsumen sadar akan merek-merek baru, mendidik mereka tentang berbagai fitur dan manfaat merek, serta memfasilitasi penciptaan citra merek yang positif. Suatu bentuk alat komunikasi yang efektif, berkemampuan menjangkau khalayak luas dengan biaya perkontak relatif rendah, periklanan memfasilitasi pengenalan merek-merek baru, meningkatkan jumlah permintaan terhadap merek-merek yang telah ada, dan meningkatkan puncak kesadaran dalam benak konsumen untuk merek-merek yang sudah ada dalam kategori produk yang matang. Kedua, mempersuasi, yang dalam hal ini iklan yang efektif akan mampu mempersuasi pelanggan untuk mencoba produk dan jasa yang diiklankan. Ketiga, mengingatkan, di mana iklan menjaga agar merek perusahaan tetap segar dalam ingatan para konsumen. Periklanan yang efektif juga meningkatkan minat konsumen terhadap merek yang sudah ada dan pembelian sebuah merek yang mungkin tidak akan dipilihnya. Keempat,

\footnotetext{
${ }^{3}$ Sonny Keraf, (2008), Etika Bisnis, Kanisius, Yogyakarta, hal. 57

${ }^{4}$ Monle Lee dan Carla Johnson, terjemah oleh Haris Munandar, (2007), Prinsip-Prinsip Pokok Periklanan Dalam Perspektif Global, Kencana, Jakarta, hal. 3
} 
memberikan nilai tambah. Dalam hal ini Periklanan memberi nilai tambah pada merek dengan memengaruhi persepsi konsumen. Periklanan yang efektif menyebabkan merek dipandang sebagai lebih elegan, lebih gaya, lebih bergengsi dan lebih unggul dari tawaran pesaing. ${ }^{5}$

Meningkatnya persaingan bisnis dalam sistem perdagangan dewasa ini membawa dampak pada mekanisme periklanan dalam rangka memberikan informasi kepada masyarakat. Oleh karena itu, diperlukan pengaturan dalam bidang periklanan agar tidak menimbulkan kerugian bagi konsumen akibat informasi yang diberikan. Adapun iklan yang merugikan bagi konsumen, meliputi

a. Bait advertising, yaitu iklan yang menarik, namun penawaran yang disampaikan tidak jujur untuk menjual produk karena pengiklan tidak bermaksud menjual barang yang diiklankan, tetapi bertujuan agar konsumen membeli barang yang diiklankan dengan barang jualan lainnya yang lebih mahal atau yang lebih menguntungkan pihak pengiklan saja.

b. Blind advertising, yaitu iklan yang cenderung membujuk konsumen untuk berhubungan dengan pengiklan, namun tidak menyatakan tujuan utama iklan tersebut untuk menjual barang atau jasa, dan tidak menyatakan identitas pengiklan.

c. False advertising, yaitu iklan untuk membujuk pembelian barang yang diiklankan, dan bujukan tersebut merugikan pembeli, serta dibuat atas dasar tindakan kecurangan atau penipuan. ${ }^{6}$

Periklanan telah mengalami suatu kemajuan yang pesat, terutama dalam strategi pemasaran modern saat ini yang tidak dipandang hanya sekedar untuk memasarkan produk yang berkualitas. Meskipun begitu, hingga saat ini belum ada peraturan perundang-perundangan yang mengatur secara khusus tentang periklanan. Dasar peraturan periklanan masih tersebar di berbagai perundangan seperti Undang-Undang Perlindungan Konsumen, Undang-Undang Informasi dan Transaksi Elektronik, dan sebagainya. Di samping itu masalah periklanan juga diatur oleh Tata Krama dan Tata Cara Periklanan Indonesia.

Di dalam Pasal 9 Undang-Undang Perlindungan Konsumen misalnya, yang menjelaskan bahwa pelaku usaha dilarang menawarkan, mempromosikan, dan mengiklankan suatu barang dan/atau jasa secara tidak benar dan atau seolah-olah produk tersebut memiliki potongan harga, keadaannya baik, memiliki sponsor, tidak mengandung cacat tersembunyi, merendahkan produk yang sejenis, menggunakan kata-kata yang berlebihan, dan mengandung janji yang belum pasti. Kemudian

\footnotetext{
${ }^{5}$ Rahmat Krisyanto. (2013), Manjemen Periklanan : Teori dan Praktek. UB Press, Jakarta, hal. 34.

${ }^{6}$ Ahmadi Miru, (2011), Prinsip-Prinsip Perlindungan Hukum Bagi Konsumen di Indonesia, PT Raja Grafindo Persada, Jakarta hal. 38
} 
dalam Pasal 10 yang berkenaan dengan informasi iklan denganmembuat penyataan yang tidak benar dan menyesatkan, baik menyangkut harga, kegunaan, kondisi, jaminan/garansi, maupun daya tarik potongan harga yang belum tentu benar. Secara khusus perbuatan yang dilarang bagi pelaku usaha periklanan diatur dalam Pasal 17 ayat (1) dengan memproduksi iklan yang dapat :

a. Mengelabui konsumen mengenai kualitas, kuantitas, bahan, kegunaan, dan harga barang dan/atau tarif jasa serta ketepatan waktu penerimaan barang dan/atau jasa;

b. Mengelabui jaminan/garansi terhadap barang dan/atau jasa;

c. Memuat informasi yang keliru, salah, atau tidak tepat mengenai barang dan/atau jasa;

d. Tidak memuat informasi mengenai risiko pemakaian barang dan/ atau jasa.

e. Mengeksploitasi kejadian dan atau seseorang tanpa seizin yang berwenang atau yang bersangkutan;

f. Melanggar etika dan/atau ketentuan peraturan perundang-undangan mengenai periklanan.

Salah satu bentuk konkrit dari pengejawantahan perlindungan kepentingan dari industri periklanan ialah dengan dibentuknya Etika Pariwara Indonesia (Tata Krama dan Tata Cara Periklanan Indonesia) yang dikeluarkan oleh Dewan Periklanan Indonesia. ${ }^{7}$ Dua hal penting yang perlu digarisbawahi dalam penyusunan EPI ini ialah bahwa etika periklanan merupakan bagian dari swakramawi (self-regulation) sehingga pengaturan dan penegakan dari EPI dilakukan oleh dan untuk para pelaku. Selain itu, Etika periklanan memiliki tempat penting dalam struktur nilai moral yang saling dukung dengan ketentuan perundang-undangan sebagai struktur nilai hukum. ${ }^{8}$ Menurut EPI, periklanan harus memuat memuat asas-asas umum, yaitu :

a. Iklan harus jujur, bertanggung jawab, dan tidak bertentangan dengan hukum yang berlaku.

b. Iklan tidak boleh menyinggung perasaan dan merendahkan martabat negara, agama, adat budaya, hukum, dan golongan.

c. Iklan harus dijiwai oleh asas persaingan yang sehat. ${ }^{9}$

\section{Perlindungan Konsumen Terhadap Pemasangan Iklan SMS Pada PT Telkomsel}

Kepastian Hukum untuk memberi perlindungan kepada konsumen berupa perlindungan terhadap hak-hak konsumen, yang diperkuat melalui undang-undang

7 Joshua Sitompul, Perlindungan Konsumen Terkait Intrusive Advertising, dalam https://www.hukumonline.com/klinik/detail/ulasan/lt54261f227c9f6/perlindungan-konsumen-terkaitintrusive-advertising/

${ }^{8} \mathrm{lbid}$

${ }^{9}$ Rhenald kasali, (2007), Manajemen Periklanan: Konsep Dan Aplikasinya Di Indonesia, Grafiti, Jakarta, hal. 156 
khusus, member Harapan agar pelaku usaha tidak bertindak sewenang-wenang yang selalu merugikan hak-hak konsumen. ${ }^{10}$ Seperti yang kita ketahui bersama bahwa kemajuan teknologi informasi pada era globalisasi ini tidaklah dapat kita pungkiri, dibuktikan dengan masyarakat sudah mempunyai alat komunikasi yaitu telephone seluler untuk membantu masyarakat berkomunikasi dengan sesamanya, tetapi itu semua tentunya mempunyai dampak positif maupun negatif bagi penggunanya.

Saat ini, kemajuan teknologi informasi tersebut banyak dimanfaatkan oleh para pelaku usaha untuk mengiklankan produknya kepada konsumen melalui kerjasama dengan perusahaan telekomunikasi Telkomsel melalui Short Message Service (SMS). Dengan adanya iklan produk melalui SMS tersebut tentu saja akan melahirkan pro dan kontra untuk masyarakat sebagai konsumen. Sebagian masyarakat tentunya merasakan manfaat, namun tidak sedikit juga yang terganggu dengan adanya iklan produk melalui SMS di telephone selular mereka.

Perlindungan konsumen mengatur hak-hak yang patut diperoleh oleh konsumen, hal ini telah diatur dalam Pasal 4 Undang-Undang Nomor 8 Tahun 1999 yang telah di jelaskan mengenai hak atas keamanan, kenyamanan, dan keselamatan konsumen dalam mengonsumsi barang dan/atau jasa.

Iklan produk melalui SMS merupakan salah satu strategi marketing yang menggunakan perangkat digital. Prinsip kerja iklan produk melalui SMS adalah server iklan mengidentifikasi perangkat ponsel terdekat dan kemudian mengirimkan SMS. Secara bisnis, iklan produk melalui SMS ini memberi kemudahan pada perusahaan iklan untuk mengiklankan usahanya dengan sasaran langsung kepada konsumen yang melintasi atau berdekatan dengan lokasi usahanya. Namun bagaimana dengan masyarakat pengguna atau konsumen provider yang menggunakan kartu prabayar Telkomsel.

Setelah melakukan penelitian dalam bentuk kuesioner terhadap beberapa orang konsumen dari berbagai kalangan yang sering kali mendapatkan iklan promosi melalui SMS dari PT Telkomsel akhirnya penulis mendapatkan informasi terhadap pemasangan iklan promosi SMS melalui PT Telkomasel dan penulis juga dapat merangkum data dari hasil penelitian dalam bentuk tabel sebagaimana dibawah ini :

\footnotetext{
${ }^{10}$ Happy Susanto,(2008), Hak-Hak Konsumen Jika dirugikan, Visi Media, Jakarta
} 
Hasil Kuisioner Terhadap Beberapa Orang Konsumen yang Menerima Iklan Promosi SMS dari PT. Telkomsel

\begin{tabular}{|l|l|c|c|c|}
\hline \multirow{2}{*}{ No. } & \multicolumn{1}{|c|}{ Pelaku Usaha } & Ya & Tidak & Jumlah \\
\cline { 2 - 4 } & $\begin{array}{l}\text { SMS iklan promosi } \\
\text { makanan dan minuman } \\
\text { masuk berulang kali }\end{array}$ & 15 & 5 & 20 \\
\hline 2. & $\begin{array}{l}\text { Informasi lokasi SMS } \\
\text { iklan promosi makanan } \\
\text { dan minuman tidak jelas }\end{array}$ & 12 & 5 & 17 \\
\hline 3. & $\begin{array}{l}\text { Iklan promosi tidak } \\
\text { sesuai dengan isi SMS }\end{array}$ & 10 & 3 & 13 \\
\hline
\end{tabular}

Berdasarkan hasil penelitian, ditemukan fakta bahwa pelaku usaha saat mengirimkan SMS iklan promosi kepada konsumen, yang dimana SMS iklan promosi berupa makanan dan minuman tersebut sering kali tidak sesuai dengan isi SMS. Kejadian seperti ini sering dialami oleh konsumen sendiri, saat ingin melakukan penawaran atas SMS iklan promosi yang ia terima, konsumen mendapati bahwa promosi makanan atau minuman yang mereka terima melalui SMS tidak sesuai dengan isi SMS tersebut dan membuat konsumen merasa tertipu akan SMS iklan promosi yang mereka terima, secara terpaksa konsumen yang sudah sampai tempat tersebut harus tetap melakukan transaksi walaupun makanan dan minuman yang mereka tidak sesuai dengan isi SMS promosi, hal ini berdampak pada ketidakpercayaan konsumen kepada promosi yang dilakukan oleh pelaku usaha.

Dengan ini, hasil penelitian yang didapatkan dari tindakan pelaku usaha menjawab mengapa konsumen yang mendapatkan iklan promosi makanan dan minuman melalui SMS harus mendapat perlindungan serta membuktikan bahwa masyarakat sebagai konsumen benar-benar harus dilindungi terlebih lagi dalam pemasangan iklan melalui SMS ini yang telah membuat konsumen merasa terancam haknya serta keselamatannya karna SMS masuk tanpa adanya persetujuan dari konsumen itu sendiri, serta informasi yang konsumen dapatkan berupa keterangan, ketentuan dan syarat yang mereka dapatkan pun tidak jelas terlebih isi dari apa yang di iklankan juga tidak sesuai dengan SMS yang konsumen terima yang akhirnya konsumen merasa tertipu dengan adanya iklan SMS tersebut. Dan pelaku usaha haruslah bertanggung jawab atas perbuatan yang mereka lakukan dimana perbuatan tersebut sudah mengancam hak-hak pribadi yang di miliki oleh konsumen. 


\section{Keuntungan dan Kerugian Bagi Konsumen Terhadap Pemasangan Iklan SMS Pada PT Telkomsel}

Hadirnya telekomunikasi digital ditengah masyarakat tentu saja sangat membantu proses pertukaran informasi antara satu dengan yang lainnya, mendapatkan informasi secara cepat tanpa harus menunggu dengan waktu yang sangat lama, dapat dengan mudah melakukan transaksi secara online jika ingin membeli suatu produk, dan mendapatkan informasi pomosi dengan mudah salah satunya adalah dengan adanya akses melalui SMS pada setiap telephone seluler, serta dengan hadirnya telekomunikasi digital ini juga dapat mempermudah masyarakat dalam memenuhi kebutuhan hidupnya sehari- hari.

Penelitian dilakukan dibeberapa restoran cepat saji serta sekaligus melakukan wawancara dengan Manager dan Staff dari tiga restoran cepat saji tersebut yaitu, Burger King, California Fried Chicken (CFC) cabang Mall Panakukang dan Dunkin Donuts Makassar. Dari hasil wawancara terhadap 3 (tiga) perusahaan tersebut penulis dapat menyimpulkan bahwa pelaku usaha yang mengiklankan produknya melalui SMS tidak semua mereka bekerja sama secara langsung dengan PT Telkomsel sebagai perantara mereka dalam mengiklankan produk, tetapi setiap restoran cepat saji mempunyai mekanismenya sendiri terhadap iklan SMS ini.

Menurut Bapak Yongki selaku Manager pada restoran cepat saji Burger King dalam mempromosikan produknya mereka bekerja sama dengan PT Telkomsel yang dimana kantor Burger King pusatlah yang bertanggung jawab atas segala promosi produk mereka melalui SMS, dan setiap kantor Burger King cabang dalam hal ini adalah cabang Burger King di kota Makassar akan mematuhi segala aturan yang sudah disampaikan dan tetapkan oleh kantor Burger King pusat yang berada di kota Jakarta, terkait dengan iklan SMS yang mereka lakukan untuk lebih banyak menarik para konsumen. (Wawancara, 29 November 2019)

Menurut Bapak Ansar selaku Manager Restoran cepat saji California Fried Chicken (CFC) cabang Mall Panakukang, yang bisa disebut dengan CFC inilah yang paling banyak iklan SMSnya dikarenakan setiap konsumen yang melewati tempat usaha tersebut pasti akan mendapatkan promo melalui SMS, dan jika konsumen sering melewati cabang-cabang CFC yang ada dikota Makassar tentunya konsumen juga akan mendapatkan iklan promo berulang kali. Sama halnya restoran cepat saji Burger King, CFC tentunya juga bekerja sama dengan PT Telkomsel dalam melakukan promosi produknya melalui SMS, yang mengatur tentang promosi melalui SMS dengan perantara PT. Telkomsel. (Wawancara, 29 November 2019)

Menurut Bapak Abdullah sebagai Staff pada toko bakery Dunkin Donuts cabang Mall Panakukang Makassar, tidak jauh berbeda dengan kedua restoran sebelumnya Dunkin Donuts dalam melakukan promosi terhadap produknya melalui SMS juga bekerja sama dengan PT Telkomsel sebagai perantara pihak 
Dunkin Donuts dengan konsumen khususnya pengguna kartu prabayar Telkomsel. (Wawancara, 29 November 2019)

Keuntungan dan kerugian yang di rasakan konsumen tentunya bermacammacam bentuknya, dan dari penelitian yang di lakukan terhadap beberapa responden, maka dapat terlihat keuntungan dan kerugian terhadap adanya pemasangan iklan SMS melalui PT Telkomsel, pada tabel dibawah ini :

Keuntungan Dan Kerugian Konsumen yang Menerima Iklan SMS Dari Pelaku Usaha Melalui PT. Telkomsel

\begin{tabular}{|c|c|}
\hline \multicolumn{2}{|c|}{ KONSUMEN } \\
\hline Keuntungan & Kerugian \\
\hline $\begin{array}{l}\text { 1. Konsumen mendapatkan } \\
\text { informasi tentang promosi suatu } \\
\text { produk }\end{array}$ & $\begin{array}{l}\text { 1. Informasi produk makanan } \\
\text { dan minuman yang didapat } \\
\text { konsumen tidak jelas }\end{array}$ \\
\hline $\begin{array}{l}\text { 2. Konsumen dapat memenuhi } \\
\text { kebutuhannya dengan memilih } \\
\text { produk yang di iklankan }\end{array}$ & $\begin{array}{l}\text { 2. Iklan promosi tidak sesuai } \\
\text { dengan isi penawaran pada } \\
\text { SMS }\end{array}$ \\
\hline $\begin{array}{l}\text { 3. Konsumen mendapatkan } \\
\text { tambahan bonus makanan dan } \\
\text { minuman dari iklan promosi } \\
\text { SMS }\end{array}$ & $\begin{array}{l}\text { 3. Lokasi tempat penukaran } \\
\text { kadang tidak jelas, sering } \\
\text { berpindah }\end{array}$ \\
\hline & $\begin{array}{l}\text { 4. Stok makanan dan minuman } \\
\text { dalam iklan promosi SMS } \\
\text { sangat terbatas }\end{array}$ \\
\hline & $\begin{array}{l}\text { 5. Harga produk makanan dan } \\
\text { minuman tidak berimbang } \\
\text { dengan bonus tambahan } \\
\text { yang didapatkan konsumen }\end{array}$ \\
\hline
\end{tabular}

Dari hasil penelitian yang didapatkan melalui penelitian lapangan ini, disebutkan ada beberapa keuntungan yang di rasakan oleh konsumen terhadap pemasangan iklan promosi melalui SMS ini, dengan adanya iklan promosi melalui SMS konsumen dapat dengan mudah memperoleh informasi tentang promosi suatu produk makanan dan minuman yang mereka terima secara langsung, dengan adanya informasi promosi yang diterima oleh konsumen tersebut konsumen juga dapat langsung melakukan penawaran terhadap produk yang dipromosikan melalui 
SMS dan langsung mendapatkan produk tersebut dengan harga yang terjangkau sesuai dengan kemampuan daya beli konsumen.

Selain beberapa keuntungan diatas, konsumen juga memperoleh keuntungan lain yang dimana konsumen mendapatkan tambahan bonus makanan atau minuman pada saat mendapatkan SMS iklan promosi. Konsumen memproleh tambahan produk entah itu berupa makanan atau minuman dari produk yang memang sudah ditetapkan oleh pelaku usaha saat promosikan produknya melalui SMS tersebut yang tentunya konsumen akan merasakan keuntungan karna mendapat tambahan bonus dari produk yang dia beli melalui SMS iklan promosi, contohnya seperti jika kita mendapat iklan promosi melalui SMS yang didalam SMS tersebut menjelaskan jika membeli satu lusin donut kita akan mendapatkan setengah lusin donut, yang artinya kita mendapat tambahan bonus berupa setengah lusin donut dari satu lusin donut yang kita beli.

Adapun juga iklan promosi melalui SMS yang masuk ke telephone seluler konsumen iklan promosinya tidak sesuai dengan isi penawaran pada SMS. Ketika konsumen melakukan penawaran atas SMS promosi yang mereka terima, mereka mendapati bahwa isi SMS promosi dan kenyataannya sangatlah berbeda jauh ketika mereka sudah ditempat usaha untuk melakukan penawaran, sehingga konsumen pasti tetap akan melakukan penawaran tersebut dan dikarenakan iklan promosi tidak sesuai dengan ini penawaran di SMS, dan dengan rasa kecewanya konsumen akan lebih banyak mengeluarkan uang dari perkiraan yang mereka duga dikarenakan ketidaksesuaian di dalam SMS iklan promosi yang ada pada mereka.

\section{Kesimpulan}

Berdasarkan hasil penelitian dan pembahasan, dapat disimpulkan bahwa konsumen pada hakikatnya perlu mendapatkan perlindungan terlebih dalam pemasangan iklan melalui SMS yang dilakukan oleh pelaku usaha dengan perantara PT Telkomsel, konsumen perlu dilindungi di karenakan perbuatan- perbuatan pelaku usaha yang dalam mengiklankan produknya melalui SMS tidak memperhatikan kepentingan dan hak- hak konsumen. Dengan adanya iklan melalui SMS ini selain mendapatkan keuntungan, konsumen ternyata lebih banyak merasakan kerugiannya. Bentuk- bentuk kerugian yang konsumen rasakan mulai dari informasi produk makanan dan minuman yang dipromosikan melalui SMS yang di dapatkan konsumen tidak sesuai bahkan ketika konsumen mendapat bonus tambahan produk makanan dan minuman harganya tidak berimbang dengan produk makanan yang di gratiskan sesuai iklan promo.

\section{REFERENSI}

Ahmadi Miru, (2011), Prinsip-Prinsip Perlindungan Hukum Bagi Konsumen di Indonesia, Jakarta: PT Raja Grafindo Persada. 
Aren Lubis, (2007), Teori-teori Periklanan Dan Unsur Periklanan, Jakarta: Universitas Indonesia.

Happy Susanto, (2008), Hak-Hak Konsumen Jika dirugikan, Jakarta: Visi Media, Jakarta. Monle Lee dan Carla Johnson, terjemah oleh Haris Munandar, (2007), Prinsip-Prinsip Pokok Periklanan Dalam Perspektif Global, Jakarta: Kencana.

Rahmat Krisyanto, (2013), Manjemen Periklanan: Teori dan Praktek. Jakarta: UB Press. Rhenald Kasali, (2007), Manajemen Periklanan: Konsep Dan Aplikasinya Di Indonesia, Jakarta: Grafiti.

Sidarta Gautama, (2004), Hukum Perlindungan Konsumen Indonesia, Edisi Revisi, Jakarta: Grasindo.

Sonny Keraf, (2008), Etika Bisnis, Yogyakarta: Kanisius.

Joshua Sitompul, Perlindungan Konsumen Terkait Intrusive Advertising, dalam https:/ / www.hukumonline.com/klinik/detail/ulasan/1t54261f227c9f6/perl indungan-konsumen-terkait-intrusive-advertising/ 